\title{
IAMJ
}

INTERNATIONAL AYURVEDIC MEDICAL JOURNAL

Research Article

ISSN: 23205091

Impact Factor: 5.344

\section{JALAUKAVACHARANA IN THE MANAGEMENT OF DIABETIC WOUND (MADHUMEHAJANYADUSHTAVRANA)}

\section{Kalpana Verma}

Assistant Professor, Department of Shalya Tantra, Institute of Ayush Medical Science, Lucknow, Uttar Pradesh, India

Corresponding Author: kalpanaverma637@gmail.com

https://doi.org/10.46607/iamj0608112020

(Published online: November 2020)

Open Access

(C) International Ayurvedic Medical Journal, India 2020

Article Received: 30/10/2020 - Peer Reviewed: 08/11/2020 - Accepted for Publication: 16/11/2020

Check for updates

\section{ABSTRACT}

Diabetic wounds have failed to proceed through an orderly and timely process to produce anatomic and functional integrity. Wounds form a very extensive and important class of the disease. Diabetic wound remains a major clinical challenge to the medical faculty throughout the world. Ayurveda the age old and holistic system of medicine offers various tools for management of Vrana. In Ayurveda Acharya Sushruta, pioneer surgeon, have mentioned various types of wound and its management. To achieve good approximation, early healing and acceptable scar, without complications Acharya Susruta has elaborately explained Shashti Upakrama. Rakta mokshana is one of them. Based on this reference, a clinical study was done with patients having clinical features of Madhumehajanyadushta vrana. So, the present study is planned to evaluate the efficacy of Jalaukavacharan in the management of diabetic wound (Madhumehajanyadushta Vrana). For these 15 patients were selected from O.P.D/ I.P.D of Shalya Tantra, N.I.A., Jaipur. The treatment was accessed with observation and results for a period of eight weeks. After this therapy, significant result was observed. It was observed that the results achieved are effective and stable during follow up period.

Keywords: Vrana, Diabetic wound, Shashti Upakrama, Rakta Mokshana, Jalaukavacharan 


\section{INTRODUCTION}

The knowledge of wound is known since antiquity. From Vedic age to modern era, man has been suffering from various ailments. Although much advancement had taken place in modern medicine to solve the problem, still they are unable to find proper solution to the utmost satisfaction. In present scenario sedentary lifestyle, a lot of stress and over nutrition are important etiology of diabetes, as one of the most prevalent diseases in the world. Diabetic wound is the most dreaded complication of diabetes mellitus. High blood glucose levels for longer durations damage blood vessels leading to reduced blood flow. This poor blood circulation contributes to the formation of ulcers and impairs wound healing. Diabetic neuropathy is most disabling as it leads to increased morbidity and decreased quality of life in patients with diabetes. Loss of sensations further lead to develop pressure spots and accidentally injure the skin, soft tissues and bones. One of the most feared complications of this disease is loss of lower limb and is a challenge to surgeons. Amount of tissue injury and degree of contamination influences the speed and quality of healing. The major part of the wound management in present days include, prevention of sepsis, various types of bandages etc. Usually parental, oral and external application of antibiotics and antiseptics are used in the treatment of ulcer which is expensive and becomes occasional reactive to the patient. In Sushruta Samhita, diabetic wound is correlated with 'Madhumehaj Vrana'. During its description, Sushruta stated that the management of these Vranas are difficult i.e. kastsadhaya ${ }^{1}$. According to Sushruta, Meda and Rakta along with other Dosha and Dushya lead to the formation of Premeha Pidika which later converted to non -healing wounds ${ }^{2 \& 3}$. There are so many factors responsible to make healing process delayed. Some of them are dead tissue, insufficient blood supply, protein deficiency, the disease like diabetes mellitus, tuberculosis etc. In case of delayed healing, it is more likely to be local than general which clarifies the magnitude of the problem of study. Even after development of different techniques and methods for the treatment of wound, still problems are persisting in the management. With review and references of ancient approaches to Vrana treatment, it is convinced that the Ayurvedic approaches to the treatment of Vrana can be better supplementation to satisfy all the above problems. Ayurveda the age old and holistic system of medicine offers various tools for management of Vrana. In Ayurveda Acharya Sushruta, pioneer surgeon, have mentioned various types of wound and its management ${ }^{4}$. To achieve good approximation, early healing and acceptable scar, without complications Acharya Susruta has elaborately explained Shashti Upakrama. Rakta Mokshana is one of them.

Aim and Objectives: The main aim of the study is to evaluate the efficacy of Jalaukavacharana in the management of the Madhumehajanyadushta Vrana (Diabetic wound). Materials and Methods: For the study, total 15 subjects were selected randomly from O.P.D/I.P.D, Department of Shalya tantra, N.I.A, Jaipur, ages ranging from 15- 70 yrs., irrespective gender, religion and socioeconomic status. The study was clearly explained to the subjects and their signed, written informed consent was taken before starting the trial. Routine blood investigations ( $\mathrm{Hb}$ gm $\%$, TLC, DLC, BT, CT, ESR, RBS, HIV \& HBsAg.) were done to every patient before starting the trial. Total time frame of the study was 12 weeks, with trial period for 8 weeks and a follow up for 4 weeks. The protocol was approved by the Institutional Ethics committee at National Institute of Ayurveda, Jaipur and the ethical approval letter's ref. number is $\mathrm{F} 10$ (5)/EC/2014/7217, dated: $7 / \mathbf{1 1} / \mathbf{2 0 1 4}$.

\section{Selection criteria:}

$>$ Inclusion Criteria: Patients having clinical features of Diabetic wound between age 15 - 70 years and those were ready to give written informed consent

> Exclusion Criteria: Malignancy, Tubercular ulcers, Syphilitic ulcers, Soft sores, Actinomycosis, Meleney's ulcers, Immuno compromised or unstable patients, HIV, immune deficiency syndrome, Immunosuppressive medications users, and patients who are not willing to give written informed consent. 
Materials used for the treatment procedure:

$\checkmark$ Jalauka, Haridra powder, Shuddha-Sphatika Bhasma.

$\checkmark$ Sterilized Gauze pieces, dressing pad, cotton, gloves.

$\checkmark$ Disposable syringe, kidney tray, distilled water, normal saline, needle.

$\checkmark$ Sterilized non-toothed forceps, scissors.

$\checkmark$ Container of sterile water, for placing leeches after they have been fed. (This container must be labeled with patient's name)

Treatment Procedure: Jalaukavacharana Vidhi

Jalaukavacharana was done in a standard protocol as described by Acharya Susruta ${ }^{6}$.

Assessment criteria: Effect of therapy was evaluated before, during $\&$ after the course of treatment by using parameters as stated below with standard grading.

a) Primary Outcome Measures:

- Circumference of the wound (Length, Width \& Depth)

- Exudate quantity

- Pain (VAS scale)

- Odour

- Granulation Tissue

b) Secondary Outcome Measures:

Recurrence: Subjects were assessed for above said variables, were recorded and stored in specific case record proforma. Privacy and confidentiality of the patients was maintained. The collected data was subjected to statistical analysis by using Stat Graph Pad 3 software (Trial version), Wilcoxon matched pairs signed ranks test, One Way ANOVA test, were used to bring out the level of significance i.e. $\mathrm{P}$ value. Photographs were taken before starting the trial, during and on $8^{\text {th }}$ week follow up or after complete healing of the wound, whichever is the earlier.

\section{Results:}

\section{Effect of therapy in individual parameters:}

Exudate: The mean Score before treatment was 1.67 which lowered down to 0.27 after treatment, with $\mathrm{SD} \pm 0.6172$ giving a relief of $83.83 \%$ and the value of $\mathbf{P}<\mathbf{0 . 0 0 0 1}$ which is statistically highly significant.

Odour: The mean Score before treatment was 0.4 which lowered down to 0.067 after treatment, with
$\mathrm{SD} \pm 0.4880$ giving a relief of $83.25 \%$ and is statistically significant with $\mathbf{P}<\mathbf{0 . 0 5}$, Granulation: The mean Score before treatment was 2.07 which lowered down to 0.47 after treatment, with $\mathrm{SD} \pm 0.7368$ giving a relief of $77.29 \%$ and is statistically highly significant with $\mathbf{P}<\mathbf{0 . 0 0 0 1}$, Pain: The mean Score before treatment was 6.46, with $\mathrm{SEM} \pm 0.59$ which lowered down to 0.46 after treatment, with $\mathrm{SEM} \pm 0.29$ giving a relief of $92.72 \%$ and is statistically highly significant with $\mathbf{P}<\mathbf{0 . 0 0 0 1}$ Circumference of wound: The mean Score before treatment was 28.60, with $\mathrm{SEM} \pm 12.71$ which lowered down to 3.05 after treatment, with $\mathrm{SEM} \pm 1.94$ giving a relief of $89.33 \%$ and is statistically non-significant with $\mathbf{P}>\mathbf{0 . 0 5}$

Recurrence: The patients who got cured completely didn't have a recurrence after a follow up for one month after the trial.

\section{DISCUSSION}

The patients treated with Jalaukavacharana had yielded better outcome with more percentage of relief in exudate, odour, granulation and circumference of the wound with highly significant $p$ values in each parameter. Jalaukavacharana has a comprehensive therapeutic influence in reducing Srava/ exudate by pacifying the vitiated Doshas and it also pacifies pitta and Rakta Dosha as they are the causative factors for Gandha. Jalaukavacharana had stimulated granulation tissue in the wound bed and this implies that it has good wound healing properties or Vrana Shodhana and Ropana properties. At the end, by assessing the $\mathrm{P}$ value and percentage of relief in different variables shown better result in wound healing where in circumference of wound decreased tremendously in a period of eight weeks trial, which confers that the rate of healing is faster with leech therapy

\section{Probable mode of action of Jalaukavacharana}

Jalaukavacharana is a biological intervention where in during blood sucking different biological secretions intervene in the healing process. This is clear from the facts that different components in the salivary secretion of the leech like Hirudin, Serotonin \& Enkephalin, Histamine like substance, Tryptase inhibitor etc have marked effects as anticoagulation, anesthetic, 
vasodilatation \& anti- inflammatory effects respectively which ultimately aid in the procedure by allowing painless, free flow of blood without any after effects as inflammation. The effect of the procedure prolongs for a considerable length due to biological secretions, till it restores the microcirculation and Doshic equilibrium and also the mechanical sucking action helps in flushing out the metabolic wastes and toxins loaded static blood from the wound bed and also from the surrounding area, which enables increase in perfusion of fresh oxygenated blood and triggers wound healing by proliferation.

\section{CONCLUSION}

The patients treated with jalaukavacharana had yielded better outcome with more percentage of relief in exudate, odour, granulation and circumference of the wound. Jalaukavacharana has a comprehensive therapeutic influence in reducing Sraval exudate by pacifying the vitiated Doshas and it also pacifies pitta and Rakta Dosha as they are the causative factors for Gandha. Jalaukavacharana had stimulated granulation tissue in the wound bed and this implies that it has good wound healing properties or Vrana Shodhana and Ropana properties.
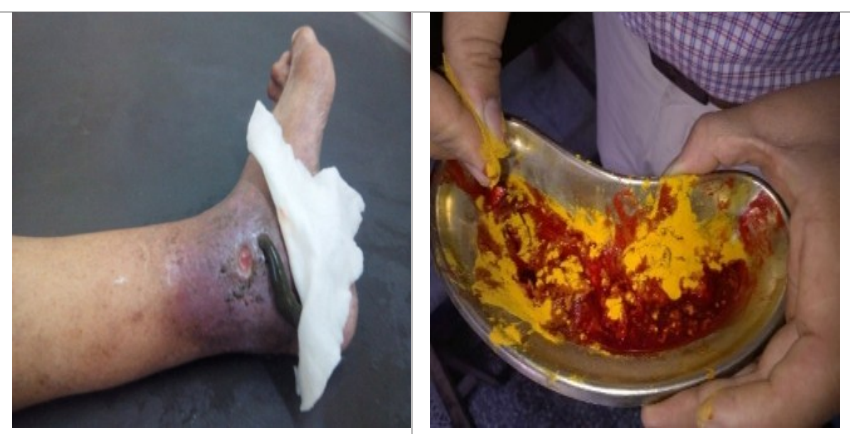

Jalauka Vacharan

Vaman
Required Materials for Jalaukavacharana Vidhi

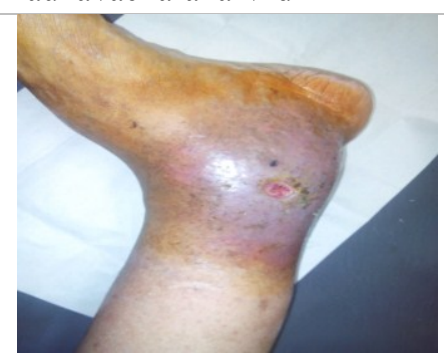

Before Treatment
Activation of Jalauka with Haridra



During Treatment

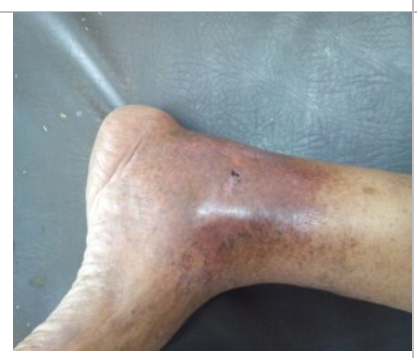

After Treatment

3. Sushruta Samhita of Sushruta Sutra sthana 23/6, with Ayurveda Tatva Sandipika hindi commentary by Kaviraja Ambika Dutta Shastri, Chaukhambha Sanskrit Sansthan Varanasi, Part 1-2,9 $9^{\text {th }}$ edition 1995.

4. Sushruta Samhita of Sushruta Chikitsa sthana 1/8 with Ayurveda Tatva Sandipika hindi commentary by Kaviraja Ambika Dutta Shastri, Chaukhambha Sanskrit Sansthan Varanasi, Part 1-2,9 ${ }^{\text {th }}$ edition 1995.

5. Sushruta Samhita of Sushruta Chikitsa sthana 1/8 with Ayurveda Tatva Sandipika hindi commentary by 
Kaviraja Ambika Dutta Shastri, Chaukhambha Sanskrit Sansthan Varanasi, Part 1-2,9 $9^{\text {th }}$ edition 1995.

6. Sushruta Samhita of Sushruta sutra sthana chapter 13 with Ayurveda Tatva Sandipika Hindi commentary by Kaviraja Ambika Dutta Shastri, Chaukhambha Sanskrit Sansthan Varanasi, Part 1-2,9 $9^{\text {th }}$ edition 1995.

\section{Source of Support: Nil}

\section{Conflict of Interest: None Declared}

How to cite this URL: Kalpana Veerma: Jalaukavacharana In The Management Of Diabetic Wound (Madhumehajanyadushtavrana). International Ayurvedic Medical Journal \{online\} 2020 \{cited November, 2020\} Available from: http://www.iamj.in/posts/images/upload/4982_4986.pdf 